\title{
Correction to: Safeguarding and using global banana diversity: a holistic approach
}

\author{
Ines Van den Houwe', Rachel Chase², Julie Sardos², Max Ruas², Els Kempenaers³, Valentin Guignon², \\ Sebastien Massart ${ }^{4}$, Sebastien Carpentier ${ }^{1}$, Bart Panis ${ }^{1}$, Mathieu Rouard ${ }^{2}$ and Nicolas Roux ${ }^{2^{*}}$
}

\section{Correction to: CABI Agric Biosci 1:15 (2020)} https://doi.org/10.1186/s43170-020-00015-6

In the original publication (Houwe et al. 2020) affiliations 1 and 2 were accidentally swapped, the error affected the affiliations of Van den Houwe, Chase, Sardos, Ruas, Guignon, Carpentier, Panis, Rouard and Roux.

This correction article shows the correct and incorrect information.

Incorrect:

${ }^{1}$ Bioversity International, Parc Scientifique Agropolis II, 34397 Montpellier, France.

${ }^{2}$ Bioversity International, Willem De Croylaan 42, 3001 Leuven, Belgium.

\section{Correct:}

${ }^{1}$ Bioversity International, Willem De Croylaan 42, 3001 Leuven, Belgium.

${ }^{2}$ Bioversity International, Parc Scientifique Agropolis II, 34397 Montpellier, France.

The original publication has been updated to reflect the correct affiliations.

\begin{abstract}
Author details
${ }^{1}$ Bioversity International, Willem De Croylaan 42, 3001 Leuven, Belgium. ${ }^{2}$ Bioversity International, Parc Scientifique Agropolis II, 34397 Montpellier, France.

${ }^{3}$ Laboratory of Tropical Crop Improvement, Division of Crop Biotechnics, KU Leuven, 3001 Leuven, Belgium. ${ }^{4}$ Integrated and Urban Plant Pathology Laboratory, Gembloux Agro-Bio Tech (GXABT), University of Liège, 5030 Gembloux, Belgium.
\end{abstract}

Published online: 18 November 2020

References

Van den Houwe I, Chase R, Sardos J, Ruas M, Kempenaers E, Guignon V, Massart S, Carpentier S, Panis B, Rouard M, Roux N. Safeguarding and using global banana diversity: a holistic approach. CABI Agric Biosci. 2020;1:15. https://doi.org/10.1186/s43170-020-00015-6.

\section{Publisher's Note}

Springer Nature remains neutral with regard to jurisdictional claims in published maps and institutional affiliations.

(c) The Author(s) 2020. This article is licensed under a Creative Commons Attribution 4.0 International License, which permits use, sharing, adaptation, distribution and reproduction in any medium or format, as long as you give appropriate credit to the original author(s) and the source, provide a link to the Creative Commons licence, and indicate if changes were made. The images or other third party material in this article are included in the article's Creative Commons licence, unless indicated otherwise in a credit line to the material. If material is not included in the article's Creative Commons licence and your intended use is not permitted by statutory regulation or exceeds the permitted use, you will need to obtain permission directly from the copyright holder. To view a copy of this licence, visit http://creativecommons.org/licenses/by/4.0/. The Creative Commons Public Domain Dedication waiver (http://creativecommons.org/publicdomain/zero/1.0/) applies to the data made available in this article, unless otherwise stated in a credit line to the data. 